\title{
Factors affecting morbidity in penetrating rectal injuries: a civilian experience
}

\author{
Penetran rektal yaralanmalarda morbiditeye etkili faktörler: Sivil deneyim
}

\author{
Metehan GÜMÜŞ, Murat KAPAN, Akın ÖNDER, \\ Abdullah BÖYÜK, Sadullah GİRGIN, İbrahim TAÇYILDIZ
}

\section{BACKGROUND}

The principles of the treatment of rectal injuries have been determined based on the experiences gained from military injuries. While adopting these principles in civilian life, it is essential to know the characteristics of civilian rectal injuries as well as the risk factors affecting morbidity.

\section{METHODS}

The characteristics of 29 inpatients who had been treated due to rectal injuries caused by gunshot wounds and penetrating devices were evaluated. In order to determine the risk factors, the patients were divided into two groups regarding the presence of morbidity (Group 1, with morbidity; Group 2, without morbidity) and compared.

\section{RESULTS}

Severe fecal contamination, perianal or gluteal injuries, duration of trauma- treatment interval, and isolated extraperitoneal injury were significant factors that affected the development of morbidity. The length of hospital stay was significantly longer in Group 1 as compared to Group 2.

\section{CONCLUSION}

Although rectal injuries are rarely encountered, they carry high morbidity and mortality. Awareness of the risk factors and planning of a patient-based treatment are essential for the success of the therapy. The rate of morbidity is substantially decreased when patients are treated in time. Thus, the awareness of both patients as well as physicians managing trauma about rectal injuries should be increased.

Key Words: Gunshot wounds; colostomy; penetrating injuries; rectal injuries; rectal repair.

\begin{abstract}
AMAÇ
Rektal yaralanmaların tedavi prensipleri savaş deneyimlerine dayanmaktadır. Sivil yaralanmalarda bu prensipleri uygularken sivil rektal yaralanmaların özelliklerini ve bunun yanında morbiditeye etkili faktörleri bilmek gerekir.

GEREÇ VE YÖNTEM

Ateşli silah ve delici-kesici aletle rektal yaralanma oluşmuş 29 hastanın özellikleri değerlendirildi. Risk faktörlerini belirlemek amaciyla hastalar morbidite olanlar ve olmayanlar şeklinde iki gruba ayrıldı (morbidite olan: Grup 1, morbidite olmayan: Grup 2) ve faktörler gruplar arasında karşılaştırıldı.
\end{abstract}

\section{BULGULAR}

Şiddetli fekal kontaminasyon, perianal veya gluteal yaralanma, travma tedavi intervali ve izole ekstraperitoneal yaralanma olması morbidite gelişimi üzerine etkili faktörlerdi. Hastanede kalış süresi Grup 1'de Grup 2 ile karşılaşt1rıldığında anlamlı derecede daha uzundu.

\section{SONUÇ}

Rektal yaralanmalarla nadiren karşılaşılmasına rağmen, morbidite ve mortalite oranları yüksektir. Risk faktörlerinin bilinmesi ve hastaya göre tedavi planı yapılması tedavinin başarısı için önemlidir. Zamanında tedavi edilen hastalarda morbidite oranı önemli ölçüde azalmaktadır. Bu nedenle, doktorların yanı sıra hastaların da rektal yaralanma konusunda bilinçli olması gerekmektedir.

Anahtar Sözcükler: Ateşli silah yaralanmaları; kolostomi; delicikesici alet yaralanmaları; rektal yaralanma; rektal onarım.
Presented at the 17th Turkish National Surgical Congress (May 26-29, 2010, Ankara, Turkey).

Department of General Surgery, Dicle University Faculty of Medicine, Diyarbakır, Turkey.
2010 Ulusal Cerrahi Kongresi’nde sözlü bildiri olarak sunulmuştur (26-29 Mayıs 2010, Ankara).

Dicle Üniversitesi Tıp Fakültesi Genel Cerrahi Anabilim Dalı, Diyarbakir. 
Penetrating trauma is the most common cause of rectal injuries. In most cases, gunshot wounds account for $80 \%-85 \%$ of the cases. Other causes of rectal injuries include stab wounds, blunt trauma, iatrogenic injuries during surgery, foreign bodies, and sexual misadventure. ${ }^{[1]}$

Although rectal injuries are rarely encountered, they are associated with high morbidity and mortality rates. ${ }^{[2]}$ The principles of the treatment of rectal injuries have been determined based on the experiences gained from high-energy injuries during wartime. Since the injuries in civilian life are low-energy injuries, direct adaptation of these principles to civilian injuries has begun to be questioned. Awareness of the characteristics of civilian rectal injury cases as well as the factors affecting morbidity and mortality will contribute to improving the treatment approaches. A specific treatment method, including primary repair, diversion, presacral drainage, distal rectal washout, and antibiotherapy, or their combinations, should be determined for each patient by evaluating specific factors, including the general status of the patient and concomitant injuries, as well as local findings, such as the site and grade of rectal injury and the presence of contamination. ${ }^{[3]}$

Knowing which patients are likely candidates for morbidity in advance and close follow-up of these patients are of great importance in determining the principles of treatment. In the present study, the factors affecting morbidity in patients with rectal injury by gunshot or stab wounds in civilian life were investigated.

\section{MATERIALS AND METHODS}

Twenty-nine inpatients, who had been treated between 2000 and 2009 in the General Surgery Clinic of Dicle University due to rectal injuries caused by gunshot and stab wounds, were included in the study. The demographic characteristics of the patients, as well as the trauma-treatment interval (TTI), length of hospital stay, concomitant organ injuries, Injury Severity Score (ISS), New Injury Severity Score (NISS), Revised Trauma Score (RTS), Trauma Injury Severity Score (TRISS), fecal contamination, and therapy methods were retrospectively recorded from the hospital records. In order to determine the factors affecting morbidity, the patients were divided into two groups regarding the presence of morbidity (Group 1, with morbidity; and Group 2, without morbidity), and the data of these two groups were compared.

Statistical analyses were performed using the Statistical Package for the Social Sciences (SPSS) version 12.0 (SPSS, Inc., Chicago, IL, USA). Data are presented as the mean \pm standard deviation or $\mathrm{n}(\%)$. One-sample Kolmogorov-Smirnov test was used to evaluate the distribution of data. The differences be- tween the subgroups were analyzed by chi-square or Fisher's exact and Mann-Whitney U tests. The correlations between variables were performed by Pearson or Spearmen's rank correlation analyses based on the distribution of data. A value of $\mathrm{p}<0.05$ was considered significant.

\section{RESULTS}

Of the patients, $28(96.6 \%)$ were male and $1(3.4 \%)$ was female. The mean age was 27.6 years (range: 18 53 years) and the mean TTI was $22.8 \pm 58.2$ hours. In 5 patients, the TTI was $>24$ hours. The mean length of hospital stay was $16.0 \pm 12.3$ days (range: 5-51 days). Gunshot wounds accounted for $69.0 \%$ of the rectal injuries. Grade 3 injury existed in $58.6 \%$ of the patients. Extraperitoneal rectal injuries were present in 19 patients $(65.5 \%)$. In 12 patients, 13 complications occurred. The general characteristics of the patients are summarized in Table 1.

Of the patients, $62.1 \%$ had concomitant organ injuries (Table 2). The most commonly associated injured organs were the intestine $(31.0 \%)$ and bladder $(27.6 \%)$. Medical therapy was administered to 1 patient and primary repair was performed on 8 patients, whereas the remaining patients received ostomies. Of the 20 patients who received ostomies, loop co-

Table 1. General characteristics of the patients

\begin{tabular}{lcc}
\hline & $\mathrm{n}$ & $\%$ \\
\hline Cause of trauma & & \\
$\quad$ Gunshot wound & 20 & 69.0 \\
$\quad$ Stab wound & 9 & 31.0 \\
Concomitant organ injury & & \\
$\quad$ Present & 18 & 62.1 \\
$\quad$ Absent & 11 & 37.9 \\
Causes of morbidity & & \\
$\quad$ Wound site infection & 8 & 27.6 \\
$\quad$ Ano-gluteal fistula & 2 & 6.9 \\
$\quad$ Vesicorectal fistula & 1 & 3.4 \\
$\quad$ Necrotizing fasciitis & 2 & 6.9 \\
Grade of injury & & \\
I & 1 & 3.4 \\
II & 10 & 34.5 \\
$\quad$ III & 17 & 58.6 \\
IV & 1 & 3.4 \\
Site of injury & & \\
$\quad$ Extraperitoneal & 19 & 65.5 \\
Intraperitoneal & 6 & 20.7 \\
$\quad$ Extra+intraperitoneal & 4 & 13.8 \\
Therapy & & \\
$\quad$ Medical & 1 & 3.4 \\
Primary repair & 8 & 27.6 \\
$\quad$ Ostomy & 20 & 69.0 \\
\hline
\end{tabular}

TTI: Trauma-treatment interval; LOHS: Length of hospital stay; SD: Standard deviation. 
Table 2. Concomitant injured organs in Groups 1 and 2

\begin{tabular}{lcc}
\hline Organs & $\begin{array}{c}\text { Group } 1(\mathrm{n}=12) \\
\mathrm{n}(\%)\end{array}$ & $\begin{array}{c}\text { Group } 2(\mathrm{n}=17) \\
\mathrm{n}(\%)\end{array}$ \\
\hline Small bowel & $2(16.7)$ & $7(41.2)$ \\
Bladder & $4(33.3)$ & $4(23.5)$ \\
Vascular & $2(16.7)$ & $3(17.6)$ \\
Pelvic bone & $2(16.7)$ & $2(11.8)$ \\
Sigmoid colon & $0(0.0)$ & $2(11.8)$ \\
Femur & $1(8.3)$ & $1(5.9)$ \\
Urethra & $2(16.7)$ & $0(0.0)$ \\
Others & $2(16.7)$ & $1(5.9)$
\end{tabular}

lostomy, Hartmann's colostomy and ileostomy were performed on $15(75.0 \%), 1(5.0 \%)$ and $4(20.0 \%)$ patients, respectively. Morbidity was recorded in 12 patients (41.4\%) (Group 1), whereas 17 patients (58.6\%) had no morbidity (Group 2). No significant difference was determined between Groups 1 and 2 with respect to concomitant organ injury and the grade of injury ( $\mathrm{p}=0.514$ for both; Table 3 ). Ostomies were performed in $91.7 \%$ of the patients in Group 1 and $52.9 \%$ of the patients in Group $2(p=0.043)$. The rate of patients with severe fecal contamination was significantly higher in Group 1 compared to Group 2 (75.0\% vs. $35.3 \%$, respectively; $\mathrm{p}=0.041$ ). The rate of perianal or gluteal injuries was significantly higher in Group 1 than Group $2(91.7 \%, p=0.032)$. No significant difference was determined between the groups in terms of extraperitoneal rectal injuries $(\mathrm{p}=0.182)$, whereas intraperitoneal injuries were higher in Group 2 (52.9\% vs. $8.3 \%, \mathrm{p}=0.016$; Table 3 ). The length of hospital stay in Group 1 was significantly longer than in Group 2 ( 27 days vs. 8.2 days, $p<0.001$; Table 4 ). A significant difference existed between the groups for both TTI $<8$ hours and $\geq 8$ hours ( $\mathrm{p}=0.038$ for Groups 1 and 2 ). The TTI was $<8$ hours in $88.2 \%$ of the patients in Group 2 (Table 3). No significant difference existed between Groups 1 and 2 with respect to the mean age $(<30$ or $\geq 30$ years), mean ISS $(<16$ or $\geq 16)$, mean RTS $(<6$ or $\geq 6$ ), and NISS values. The mean TRISS value was $97.3 \pm 2.7$ in Group 1 and $97.8 \pm 2.6$ in Group 2 (Table 4). There was a significant positive correlation between the grade of injury and the number of concomitant organ injuries $(r=0.430, p=0.02$; Table $5)$. A negative correlation was determined between the number of concomitant injured organs and the TTI $(\mathrm{r}=-0.405, \mathrm{p}=0.029)$ and between the NISS and TTI $(\mathrm{r}=-0.436, \mathrm{p}=0.018$; Table 5). One of the patients died of necrotizing fasciitis due to a delay in diagnosis. The mortality rate was determined to be $3.4 \%$.

\section{DISCUSSION}

The treatment of rectal injuries has four main components: 1) fecal diversion; 2) presacral drainage; 3) distal rectal washout; and 4) rectal repair, if possible. ${ }^{[1]}$
Table 3. Comparison of the characteristics of the patients in Group 1 and Group 2

\begin{tabular}{|c|c|c|c|}
\hline & $\begin{array}{c}\text { Group } 1(\mathrm{n}=12) \\
\mathrm{n}(\%)\end{array}$ & $\begin{array}{c}\text { Group } 2(\mathrm{n}=17) \\
\mathrm{n}(\%)\end{array}$ & $\mathrm{p}$ \\
\hline \multicolumn{4}{|l|}{ Age (years) } \\
\hline$<30$ & $7(58.3)$ & $12(70.6)$ & \multirow[t]{2}{*}{0.432} \\
\hline$\geq 30$ & $5(41.7)$ & $5(29.4)$ & \\
\hline \multicolumn{4}{|l|}{ TTI (hours) } \\
\hline$<8$ & $6(50.0)$ & $15(88.2)$ & \multirow{2}{*}{0.038} \\
\hline$\geq 8$ & $6(50.0)$ & $2(11.8)$ & \\
\hline \multicolumn{4}{|l|}{ ISS } \\
\hline$<16$ & $5(41.7)$ & $6(35.3)$ & \multirow[t]{2}{*}{0.514} \\
\hline$\geq 16$ & $7(58.3)$ & $11(64.7)$ & \\
\hline \multicolumn{4}{|l|}{ RTS } \\
\hline$<6$ & $0(0.0)$ & $1(5.9)$ & \multirow[t]{2}{*}{0.586} \\
\hline$\geq 6$ & $12(100.0)$ & $16(94.1)$ & \\
\hline \multicolumn{4}{|l|}{ Etiology } \\
\hline GSW & $8(66.7)$ & $12(70.6)$ & \multirow[t]{2}{*}{0.568} \\
\hline SW & $4(33.3)$ & $5(29.4)$ & \\
\hline \multicolumn{4}{|l|}{ Grade } \\
\hline I-II & $5(41.7)$ & $6(35.3)$ & \multirow[t]{2}{*}{0.514} \\
\hline III-IV & $7(58.3)$ & $11(64.7)$ & \\
\hline \multicolumn{4}{|l|}{$\mathrm{COI}$} \\
\hline Yes & $7(58.3)$ & $11(64.7)$ & \multirow[t]{2}{*}{0.514} \\
\hline No & $5(41.7)$ & $6(35.3)$ & \\
\hline \multicolumn{4}{|l|}{ Ostomy } \\
\hline Yes & $11(91.7)$ & $9(52.9)$ & \multirow[t]{2}{*}{0.043} \\
\hline No & $1(8.3)$ & $8(47.1)$ & \\
\hline \multicolumn{4}{|c|}{ Fecal contamination } \\
\hline Major & $9(75.0)$ & $6(35.3)$ & \multirow[t]{2}{*}{0.041} \\
\hline Minimal-Mild & $3(25.0)$ & $11(64.7)$ & \\
\hline \multicolumn{4}{|l|}{ POG injury } \\
\hline Yes & $11(91.7)$ & $9(52.9)$ & \multirow[t]{2}{*}{0.032} \\
\hline No & $1(8.3)$ & $8(47.1)$ & \\
\hline \multicolumn{4}{|l|}{ EP injury } \\
\hline Yes & 11 (91.7) & $12(70.6)$ & \multirow[t]{2}{*}{0.182} \\
\hline No & $1(8.3)$ & $5(29.4)$ & \\
\hline \multicolumn{4}{|l|}{ IP injury } \\
\hline Yes & $1(8.3)$ & $9(52.9)$ & \multirow{2}{*}{0.016} \\
\hline No & 11 (91.7) & $8(47.1)$ & \\
\hline
\end{tabular}

LOHS: Length of hospital stay; TTI: Trauma-treatment interval; ISS: Injury severity score; RTS: Revised trauma score; COI: Concomitant organ injury; POG: Perianal or gluteal; EP: Extraperitoneal; IP: Intraperitoneal.

Table 4. Characteristics of the patients in Group 1 and Group 2 and their comparisons

\begin{tabular}{lccc}
\hline & $\begin{array}{c}\text { Group 1 }(\mathrm{n}=12) \\
\text { Mean } \pm \text { SD }\end{array}$ & $\begin{array}{c}\text { Group 2 }(\mathrm{n}=17) \\
\text { Mean } \pm \text { SD }\end{array}$ & $\mathrm{p}$ \\
\hline Age (year) & $28.00 \pm 9.9$ & $27.3 \pm 6.3$ & 0.912 \\
LOHS (days) & $27.0 \pm 12.4$ & $8.2 \pm 2.2$ & $<\mathbf{0 . 0 0 1}$ \\
TTI (hours) & $50.0 \pm 85.0$ & $3.5 \pm 2.2$ & 0.103 \\
ISS & $15.5 \pm 6.5$ & $14.9 \pm 4.8$ & 0.744 \\
RTS & $7.5 \pm 0.6$ & $7.6 \pm 0.7$ & 0.679 \\
TRISS & $97.3 \pm 2.7$ & $97.8 \pm 2.6$ & - \\
NISS & $18.2 \pm 7.1$ & $18.2 \pm 6.1$ & 0.744 \\
\hline
\end{tabular}

LOHS: Length of hospital stay,; TTI: Trauma-treatment interval; ISS: Injury severity score; RTS: Revised trauma score; TRISS: Trauma injury severity score; NISS: New injury severity score; SD: Standard deviation. 
Table 5. The correlation coefficients between the studied variables

\begin{tabular}{lccccc}
\hline & Number of COI & TTI & ISS & RTS & NISS \\
\hline Grade & $\mathbf{0 . 4 3 0 *}$ & -0.185 & $\mathbf{0 . 9 0 5 * *}$ & -0.200 & $\mathbf{0 . 7 8 0 * *}$ \\
Number of COI & - & $\mathbf{- 0 . 4 0 5 *}$ & $\mathbf{0 . 6 1 3 * *}$ & -0.353 & $\mathbf{0 . 8 0 0 * *}$ \\
TTI & - & - & -0.150 & 0.093 & $\mathbf{- 0 . 4 3 6 *}$ \\
ISS & - & - & - & -0.194 & $\mathbf{0 . 8 5 1 * *}$ \\
RTS & - & - & - & - & $\mathbf{- 0 . 4 0 6 *}$ \\
\hline
\end{tabular}

${ }^{*} \mathrm{p}<0.05,{ }^{*} \mathrm{p}<0.001$. COI: Concomitant organ injury; TTI: Trauma-treatment interval; ISS: Injury severity score; RTS: Revised trauma score; NISS: New injury severity score.

The principles of the treatment of rectal injuries have been determined based on the experiences gained from high-energy injuries during wartime. Since the injuries in civilian life are low-energy injuries, direct adaptation of these principles to civilian injuries has begun to be questioned. In a recent study, the mortality rate was reported to be $18 \%$ among 175 patients with colorectal injuries who had been treated at the 31 st Combat Support Hospital during Operation Iraqi Freedom. The mortality rate among 3267 patients treated for other reasons in the same hospital was $8 \%$ during the same period of time. ${ }^{[4]}$ The morbidity and mortality rates in a civilian rectal injury series have been reported to be $6 \%-42 \%$ and $0 \%-10 \%$, respectively. ${ }^{[5]}$ In a more recent study performed on 19 civilian patients with extraperitoneal rectal injuries, and 4 civilian patients with both intra- and extraperitoneal rectal injuries, Shatnawi and Bani-Hani ${ }^{[6]}$ reported the morbidity and mortality rates as $47.8 \%$ and $13 \%$, respectively. In the present study, the overall morbidity and mortality rates were $41.4 \%$ and $3.4 \%$, respectively. The morbidity rate for those with extraperitoneal rectal injuries was $47.8 \%$.

In the present study, the fact that no mortality was determined in patients treated in time indicated the efficacy of the treatment modalities used in the management of patients with rectal injuries. Mortality occurred in only one patient in whom an extraperitoneal rectal injury had been recognized after the development of necrotizing fasciitis during the emergent operation in the orthopedics clinic. Unless rectal injuries are diagnosed and treated properly, they can lead to high-risk injuries. Rectal injuries cannot be noticed due to the anatomic localization of the area if they are not examined carefully. ${ }^{[6]}$ A digital rectal examination should be performed in patients with gross rectal blood, wounds in close proximity, pelvic fractures, injuries to the genitourinary tract, and lower abdominal pain or tenderness, which suggest the possibility of a rectal injury. ${ }^{[6]}$ A proctosigmoidoscopic examination should be performed in case of any suspicious findings, and sphincter tone must be checked during the examination. A negative digital rectal examination does not exclude the diagnosis of rectal injury. Therefore, further examinations should be performed in cases of suspected rectal injuries, including cystoure- thrograms, abdominal and pelvic X-rays, water-soluble contrast studies, peritoneal lavage, and computed tomography (CT) scanning. ${ }^{[2]}$

In the treatment of extraperitoneal rectal injuries, a diverting colostomy has been accepted as the standard therapy by many authors. ${ }^{[7-9]}$ It has been reported that extraperitoneal rectal injuries can be safely treated with fecal diversion alone, particularly in low-velocity trauma. ${ }^{[10,11]}$ Bostick et al. ${ }^{[7]}$ reported that no septic complications were observed in any of the cases that underwent loop colostomies. Demirbaş et al. ${ }^{[12]}$ verified the therapeutic approach consisting of a diverting colostomy (by performing a loop colostomy on all patients), distal rectal washout and presacral drainage in the treatment of ano-rectal gunshot injuries. In the present study, a loop colostomy was performed in 15 of the patients who had undergone ostomies; 1 patient underwent Hartmann's procedure for technical reasons, and in 4 patients, the rectum was primarily repaired and an ileostomy was performed.

Anterior and lateral upper two-thirds rectal wounds are intraperitoneal and should be treated similar to colon injuries. Anterior lower one-third and posterior lower two-thirds rectal injuries are extraperitoneal and can be managed by primary repair on a case-by-case basis. ${ }^{[2]}$ Some authors have suggested that primary repair without diversion is feasible in selected patients. ${ }^{[13-15]}$ In a study involving 30 patients with extraperitoneal rectal injuries, Levine et al. ${ }^{[15]}$ suggested that primary repair without fecal diversion could be considered in patients without major associated injuries when they were treated within 8 hours of injury and had rectal injury scores (RIS) $\leq 2$. However, the repair of extraperitoneal rectal perforations is not always technically feasible, and there is very little evidence to support the primary repair of these injuries ${ }^{[11]}$ Fecal diversion without primary repair is a safe procedure due to the anatomic considerations and technically difficult dissections. Those who advocate fecal diversion have suggested that the incidence of septic complications is less with diversion and have also shown that the incidence of stoma closure is associated with acceptable morbidity. ${ }^{[16]}$ Primary repair is recommended in only one-half of the cases with extraperitoneal 
rectal injuries if it is possible to locate the wound. ${ }^{[7]}$ The success rate of primary repair in a civilian series has been reported to be higher as compared to a military series. ${ }^{[4]}$ Bostick et al. ${ }^{[7]}$ performed primary repair to $32.1 \%$ of 28 extraperitoneal rectal injury cases. In the present study, primary repair or medical treatment were performed on $9(31 \%)$ of the cases. Burch et al. ${ }^{[5]}$ reported that colostomy and drainage were successful in the treatment of civilian rectal injuries, whereas additional procedures, such as diverting colostomies, rectal wound repairs and rectal irrigation had minimal effects on morbidity and mortality.

In the present study, the TTI was $\geq 8$ hours in 8 patients, while it was $>24$ hours in 5 of these patients. Of the 5 patients, the reason for the delay was misdiagnosis in 2 patients, and ignorance and embarrassment in 3 patients. Owing to the fact that those with trans-anal rectal injuries in particular are admitted late due to social reasons, complications associated with wound infections are likely to be encountered more often. ${ }^{[17]}$ Shatnawi and Bani-Hani ${ }^{[6]}$ reported an association between wound infections and a treatment delay $>6$ hours. The duration of the TTI also increases the rate of fecal contamination. In addition to enhancing the technical capabilities, the awareness of patients and physicians about rectal injuries should be increased in an effort to shorten the TTI.

In the present study, the majority of the patients without morbidity $(88.2 \%)$ were in the group with a shorter TTI ( $<8$ hours). The frequency of concomitant organ injury increased as the grade of rectal injury increased, and the TTI was shortened in those with increased concomitant organ injury. Early treatment lowers the rate of morbidity. In the present study, an increase was determined in the frequency of concomitant organ injury with an increasing grade of injury. A negative correlation was found between the increase in the frequency of concomitant organ injury and the duration of the TTI. Thus, although the likelihood of morbidity is high in patients with a high-grade injury and a high number of concomitant injured organs, we believe that early treatment leads to a decrease in the morbidity rate. Furthermore, it is suggested that intraperitoneal injury symptoms that occur in the early stages prevent the delay in diagnosis and treatment; thus, the rate of morbidity is lower in such patients due to early treatment. Intraperitoneal injuries cause an acute abdomen and lead the patients to seek care in health centers and with physicians thus enabling an early intervention. It was observed that the rate of morbidity was higher $(91.7 \%)$ in the group without intraperitoneal injuries (the group with isolated extraperitoneal injuries). A limited number of symptoms in isolated extraperitoneal injuries and a delay in diagnosis particularly in occult injuries may lead to higher rates of morbidity.
Genitourinary tract injuries are among the most common lesions associated with rectal trauma. Injury to the bladder alone has been reported in approximately $30 \%$ of patients with rectal injuries. ${ }^{[7,11]}$ Concomitant colon injuries have been reported in approximately $25 \%$ of patients with rectal injuries. ${ }^{[7]}$ In their series of 17 patients with combined penetrating rectal and genitourinary tract injuries, Franko et al. ${ }^{[18]}$ showed a high complication rate, including a rectovesical/urethral fistula rate of $24 \%$. Crispen et al. ${ }^{[19]}$ reported that patients sustaining combined penetrating injuries involving the rectum and bladder did not have an increased rate of immediate postoperative complications compared with isolated injuries. In the present study, there were 8 patients $(27.6 \%)$ with bladder injuries. Of those, one patient had a rectovesical fistula that healed spontaneously with prolonged urethral catheter drainage. Intestinal injuries were noted in 9 patients as well (31.0\%).

It has been reported that the presence of shock on admission and delay in treatment have an effect on wound infections. ${ }^{[6]}$ In one study, it was noted that an abdominal trauma index $>16$, RTS $<6$, blood transfusion of $>10$ units, and not applying rectal irrigation are effective factors in the development of pelvic abscesses. ${ }^{[20]}$ Bostick et al. ${ }^{[7]}$ did not report any septic complications in 28 patients, including those in whom presacral drainage was not performed $(n=3)$.

In the present study, fecal contamination, perianal or gluteal injuries, the duration of the TTI, and isolated extraperitoneal injuries were significant factors affecting the morbidity rate. The length of hospital stay was significantly longer in Group 1 compared to Group 2.

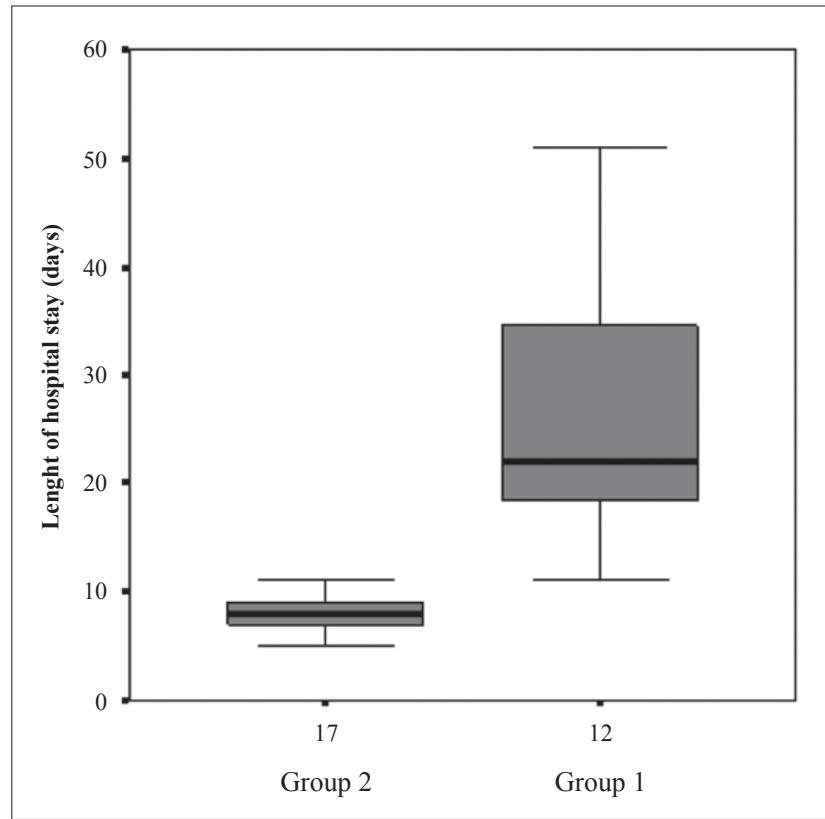

Fig. 1. The association of morbidity with the length of hospital stay. 
The development of morbidity prolongs the length of hospital stay in addition to its negative effects on health. Levy et al. ${ }^{[21]}$ reported the length of hospital stay to be 21 days (range: 10 days to 4 months) in civilian extraperitoneal rectal injury cases. The length of hospital stay in the present study ranged from 5-51 days and was $27.0 \pm 12.4$ days on average in Group 1 . The length of hospital stay was significantly longer in Group 1 than in Group 2 (Fig. 1).

In conclusion, a TTI $>8$ hours, the presence of perianal or gluteal injuries and the presence of fecal contamination were significant factors that affected the development of morbidity in penetrating rectal injuries. A positive correlation was demonstrated between the grade of injury and the number of concomitant injured organs and NISS, whereas there was a negative correlation with the TTI. It was concluded that a more severe clinical entity facilitates the early initiation of treatment and a decrease in morbidity. In order to diagnose and treat in time, the awareness of both patients and physicians about rectal injuries should be increased. Primary repair is adequate in those presenting within 8 hours with low-grade injuries but without fecal contamination, accompanying perianal defects and sphincter injuries and concomitant organ and system injuries. If the above-mentioned features do not present, ostomy should be included in the current treatment. Distal washout and presacral drainage may be applied in selected cases.

\section{REFERENCES}

1. Demetriades D, Salim A. Colon and rectal trauma and rectal foreign bodies. In: Wolff BG, Fleshman JW, Beck DE, et al., editors. The ASCRS Textbook of Colon and Rectal Surgery. New York, NY: Springer Science \& Business Media; 2007. p. 322-34.

2. Cleary RK, Pomerantz RA, Lampman RM. Colon and rectal injuries. Dis Colon Rectum 2006;49:1203-22.

3. Weinberg JA, Fabian TC, Magnotti LJ, Minard G, Bee TK, Edwards N, et al. Penetrating rectal trauma: management by anatomic distinction improves outcome. J Trauma 2006;60:508-14.

4. Steele SR, Wolcott KE, Mullenix PS, Martin MJ, Sebesta JA, Azarow KS, et al. Colon and rectal injuries during Operation Iraqi Freedom: are there any changing trends in management or outcome? Dis Colon Rectum 2007;50:870-7.

5. Burch JM, Feliciano DV, Mattox KL. Colostomy and drainage for civilian rectal injuries: is that all? Ann Surg
1989;209:600-11.

6. Shatnawi NJ, Bani-Hani KE. Management of civilian extraperitoneal rectal injuries. Asian J Surg 2006;29:11-6.

7. Bostick PJ, Johnson DA, Heard JF, Islas JT, Sims EH, Fleming AW, et al. Management of extraperitoneal rectal injuries. J Natl Med Assoc 1993;85:460-3.

8. Navsaria PH, Graham R, Nicol A. A new approach to extraperitoneal rectal injuries: laparoscopy and diverting loop sigmoid colostomy. J Trauma 2001;51:532-5.

9. Navsaria PH, Shaw JM, Zellweger R, Nicol AJ, Kahn D. Diagnostic laparoscopy and diverting sigmoid loop colostomy in the management of civilian extraperitoneal rectal gunshot injuries. Br J Surg 2004;91:460-4.

10. Velmahos GC, Gomez H, Falabella A, Demetriades D. Operative management of civilian rectal gunshot wounds: simpler is better. World J Surg 2000;24:114-8.

11. Navsaria PH, Edu S, Nicol AJ. Civilian extraperitoneal rectal gunshot wounds: surgical management made simpler. World J Surg 2007;31:1345-51.

12. Demirbaş S, Yildiz M, Uluutku AH, Kalemoğlu M, Kurt Y, Erenoğlu C, et al. Surgical treatment of ano-rectal gunshot injuries caused by low-velocity bullets. Ulus Travma Acil Cerrahi Derg 2004;10:17-21.

13. Thomas DD, Levison MA, Dykstra BJ, Bender JS. Management of rectal injuries. Dogma versus practice. Am Surg 1990;56:507-10.

14. Ivatury RR, Licata J, Gunduz Y, Rao P, Stahl WM. Management options in penetrating rectal injuries. Am Surg 1991;57:50-5.

15. Levine JH, Longo WE, Pruitt C, Mazuski JE, Shapiro MJ, Durham RM. Management of selected rectal injuries by primary repair. Am J Surg 1996;172:575-9.

16. Berne JD, Velmahos GC, Chan LS, Asensio JA, Demetriades D. The high morbidity of colostomy closure after trauma: further support for the primary repair of colon injuries. Surgery 1998; 123:157-64.

17. El-Ashaal YI, Al-Olama AK, Abu-Zidan FM. Trans-anal rectal injuries. Singapore Med J 2008;49:54-6.

18. Franko ER, Ivatury RR, Schwalb DM. Combined penetrating rectal and genitourinary injuries: a challenge in management. J Trauma 1993;34:347-53.

19. Crispen PL, Kansas BT, Pieri PG, Fisher C, Gaughan JP, Pathak AS, et al. Immediate postoperative complications of combined penetrating rectal and bladder injuries. J Trauma 2007;62:325-9.

20. Gonzalez RP, Falimirski ME, Holevar MR. The role of presacral drainage in the management of penetrating rectal injuries. J Trauma 1998;45:656-61.

21. Levy RD, Strauss P, Aladgem D, Degiannis E, Boffard KD, Saadia R. Extraperitoneal rectal gunshot injuries. J Trauma 1995;38:273-7. 